\title{
Effect of Core Magnetic Saturation on Cogging Torque of Motor
}

\author{
S. Iwasa and C. Kaido \\ Kitakyushu National College of Technology, 5-20-1 Shii, Kokuraminami-ku, Kitakyushu 802-0985, Japan
}

\begin{abstract}
This paper discusses what effects of magnetization saturation has on the cogging torques of 12-pole motors with 9slot cores, using $\mathrm{Nd}-\mathrm{Fe}-\mathrm{B}$ ring magnets. The core flux density is changed with sintered, bonded and thermally demagnetized magnets. Cogging torques especially 36th harmonics, increase with the higher flux densities of the core at the teeth, and then magnetic saturation makes cogging torques larger. However, the harmonics of core flux densities are low although 36th cogging torques are related to the harmonics of core flux. Therefore, increasing cogging torques with magnetization saturations may be affected by the reduction in permeabilities due to magnetic saturations and the generation of core-flux density harmonics.
\end{abstract}

Key words: motor, cogging torque, core, magnetic saturation

\section{モータのコギングトルクに及ぼす鉄心磁気飽和の影響}

岩佐 心平 · 開道 力

北九州工業高等専門学校, 北九州市小倉南区 5-20-1（广802-0985）

\section{1. 緒言}

最近，小型モータの用途が増え，モータの性能向上，特 に，鉄損やコギングトルクの低減が求められている．高卜 ルク化のため, 希土類磁石が多くなり, 鉄心磁束密度の上 昇で鉄損やコギングトルクが増加してきている ${ }^{1)}$.

コギングトルクはトルク品質向上のため，定格トルクの $1 \%$ 以下 の低減要求は高く, 永久磁石の着磁分布や鉄心 形状の最適化により，低コギングトルク化が進められてき ている.

このような背景において，モータの鉄損やコギングトル クの低減が数值解析などで検討されている ${ }^{2)}$. また, 実際 のモータ鉄心には, 希土類磁石使用により鉄心が磁気飽和 し，また鉄心加工により鉄心は劣化し，鉄損やコギングト ルクの増加を引き起こすことが報告されている ${ }^{3)}$.

しかし，磁気飽和などによるコギングトルク増加につい て，更に詳しい実測などの定量的な解析が必要であり，実 際のモータにおける低コギングトルク設計に結びつけるた めには磁気飽和状態のモデリングの確立が必要である.

本報告では，モータの高性能化とモータ性能予測技術確 立のために, 低磁束密度ではコギング低減対策が成されて いる 12 極 9 スロットモータを用いて, 界磁磁石を高エネ ルギー積の磁石に変えて鉄心を磁気飽和させることによ り，コギングトルクの発生状況を定量的に調べたので報告 する.

\section{2. 実測}

\section{1 コギングトルクの測定}

実験では, Fig.1 に示す 12 極 9 スロットのブラシレス DC モータを用いた。

回転子には $\mathrm{Nd}-\mathrm{Fe}-\mathrm{B}$ リング磁石（内径 $20.7 \mathrm{~mm}$, 厚さ 1 $\mathrm{mm}$, 幅 $6.2 \mathrm{~mm}$ ) と $1 \mathrm{~mm}$ 厚継鉄を用いた.

$\mathrm{Nd}-\mathrm{Fe}$-B リング磁石は着磁磁束密度の高い焼結磁石と着 磁磁束密度が低いボンド磁石の二種類用い, 鉄心の磁気飽
和状態から低磁束密度までの範囲でコギングトルクに及ぼ す磁束密度の影響を調べた。

使用したボンド磁石は, Fig.1 のモータ状態でコギングト ルクの低減が検討され，着磁分布が最適化されている。一 方，焼結磁石は保磁力が大きいため, サイズと極数により 着磁分布の最適化が難しく着磁分布の最適化は成されてい ない.

更に，鉄心の磁束密度の影響を詳細に調べるため，焼結 磁石とボンド磁石共に熱減磁させて着磁磁束密度を変化さ せ，鉄心磁束密度を細かく変化させた．鉄心磁束密度を磁 石ごとに歯部においる磁束密度最大值で示したものが Table 1 である.

固定子には無方向性電磁鋼板 (0.35 mm 厚, $3 \mathrm{wt} \% \mathrm{Si}$, 歪取焼鈍なし) の打抜加工鉄心（外径 $20.2 \mathrm{~mm}$, 内径 8.2 $\mathrm{mm}$, 積厚 $4.9 \mathrm{~mm}$ 継鉄幅約 $1.5 \mathrm{~mm}$, 歯幅 $1.6 \mathrm{~mm}$, スロ ット閉口角 $10^{\circ}$, 丸平カシメ 3 個, ピン溝 1 個） 35A2504) を用いた。

コギングトルク，誘起起電力の両測定を行う際は Fig.2 のようにモータ状態にして行った。

モータ（駆動電流なし）の回転子を外部 5 相ステッピング モータのマイクロステップ駆動で一回転 200 秒と非常に低 い速度で回転させながら, 軸受け部分から出ているアーム とひずみゲージのアームを垂直に設置することで回転子に 誘起されるトルクを測定した。コギングトルクはこの誘起 トルクの波形変化より求めた.

今回使った回転子の中で, 最大の着磁磁束密度である焼 結磁石 $\mathrm{S} 1$ と最小の着磁磁束密度であるボンド磁石 B10の 場合についてコギングトルクを比較したものが Fig.3 であ る. 非常に大きい差があり全体的に焼結磁石はボンド磁石 よりもコギングトルクが大きくなっていた．この理由とし てボンド磁石を用いたモータはコギングトルク低減が既に なされた量産品であると共に, 着磁磁束密度が低く磁気飽 和の影響が小さいためと考えられる. 


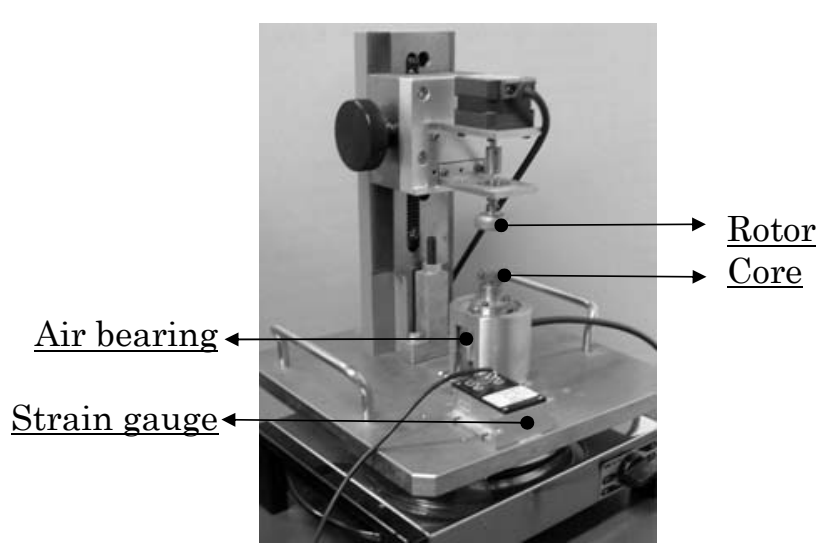

(1) Torque measuring system

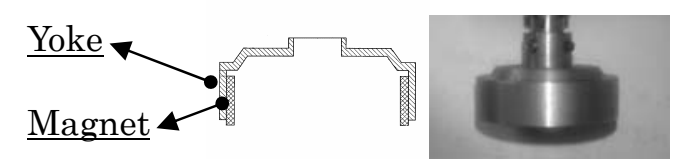

(2) Rotor

(3) Core
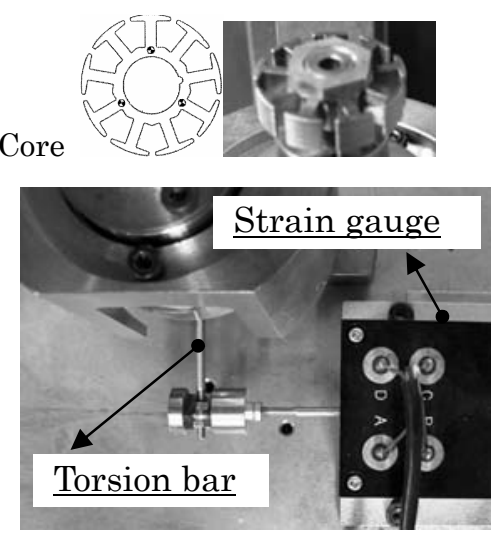

(4) How to measure induced torque.

Fig. 1 Configuration of rotor and stator core in evaluated motor.

Table 1 Flux density of core at teeth.

\begin{tabular}{|c|c|c|c|}
\hline \multicolumn{5}{|c|}{ Bonded magnetic rotor } \\
\hline No. & $B_{\text {MAX }}[\mathrm{T}]$ & No. & $B_{\text {MAX }}[\mathrm{T}]$ \\
\hline B1 & 1.03 & B6 & 0.95 \\
\hline B2 & 0.99 & B7 & 0.93 \\
\hline B3 & 0.98 & B8 & 0.84 \\
\hline B4 & 0.96 & B9 & 0.77 \\
\hline B5 & 0.96 & B10 & 0.68 \\
\hline \multicolumn{5}{|c|}{ Sintered magnetic rotor } \\
\hline No. & $B_{\text {MAX }}[\mathrm{T}]$ & No. & $B_{\text {MAX }}[\mathrm{T}]$ \\
\hline S1 & 1.63 & S5 & 0.98 \\
\hline S2 & 1.60 & S6 & 0.95 \\
\hline S3 & 1.60 & S7 & 0.87 \\
\hline S4 & 1.29 & S8 & 0.87 \\
\hline
\end{tabular}

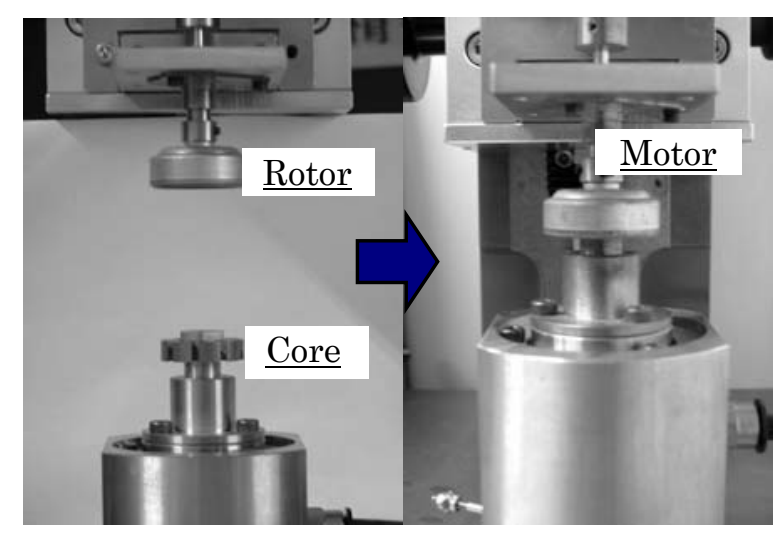

Fig. 2 Setup for torque measurements of evaluated motor.

\section{2 誘起起電力の測定}

誘起起電力波形をコギングトルクと磁気飽和の関係を検 討するため測定した。 2.1 で使用した Fig.1 1 示す 12 極 9 スロットのブラシレス DC モータにおいて, Table.1に示し た各焼結磁石の回転子と各ボンド磁石の回転子について, 固定子鉄心に $3 \mathrm{wt} \% \mathrm{Si}$ 無方向性電磁鋼板を用い，その鉄心 歯部の誘起起電力波形を測定した。この誘起起電力誘波形 より, 鉄心の最大磁束密度と磁気飽和で生じる磁束密度の 高調波成分を求めた。

誘起起電力は，外部からスピンドルモータで回路スピー ドを調整し $6684 \mathrm{r} / \mathrm{min}$ の速度で回転させ，固定子鉄心の 歯，3 箇所（3 スロットごとに 10 回巻き）に巻いたサーチ コイルを用いて測定した。このようにして回転子磁石別誘 起起電力を実測した．誘起起電力から鉄心磁束密度を求め た.

鉄心磁束密度に関しては Table.1 に示しているように磁 束密度最大の磁石と磁束密度最小の磁石では Fig.4のよう に差があった。

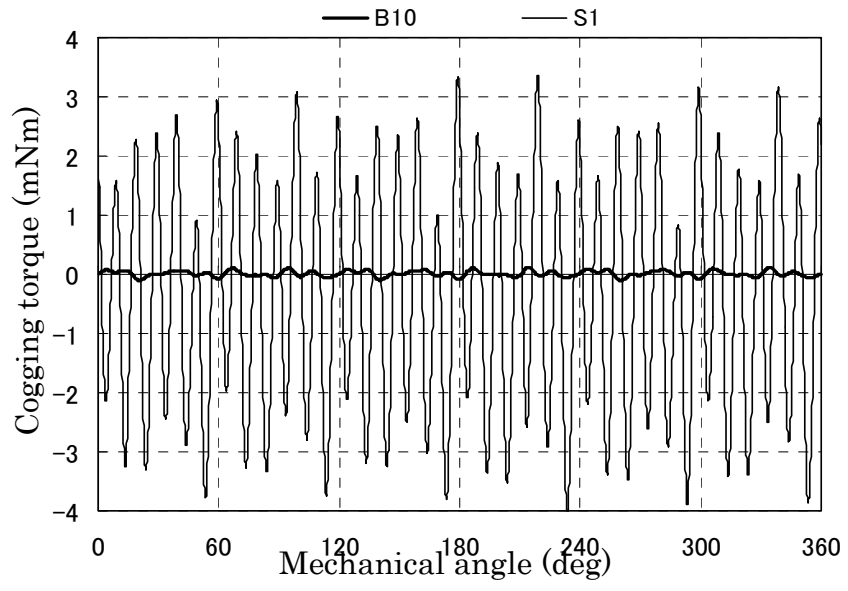

Fig. 3 Cogging torques compared with maximum and minimum flux densities. 


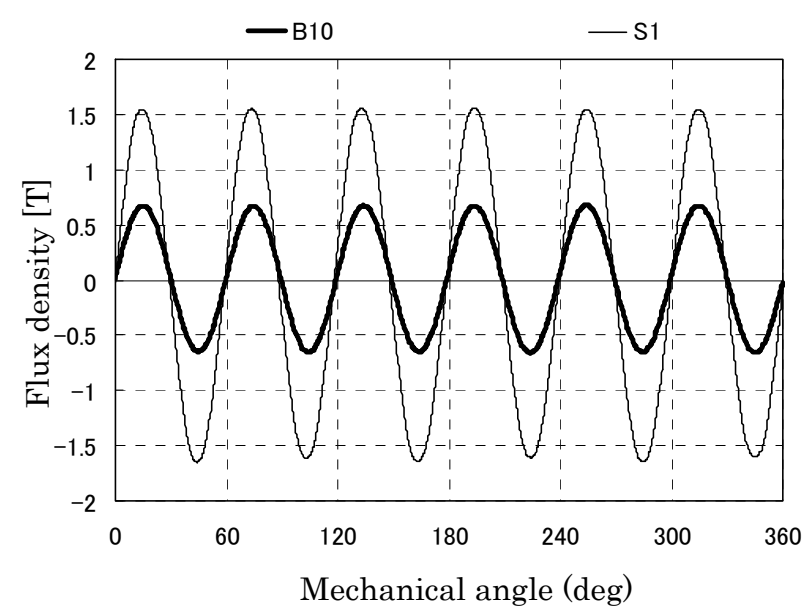

Fig. 4 Flux density waveform compared with maximum and minimum flux densities.

\section{3. コギングトルクの高調波解析}

本実験の目的としては回転子磁石別コギングトルクと誘 起起電力を実測し, 基本波や高調波を求めることで各々の 次数に関連した規則性をみいだし，それらを数值化しグラ フ化することでコギングトルクと誘起起電力の関係性を把 握することにある.

\section{1 コギングトルクの高調波次数}

ここでは Fig.3 に示したコギングトルクから高調波次数 ごとの振幅を示した．基本波周波数は固定子回転数に対応 した周波数とし，使用した永久磁石は 12 極なので，着磁磁 束密度の基本波は 6 次となる. Fig. 5 , Fig.6 には回転子磁石 別にまとめグラフ化したものである.

グラフの縦軸はボンド磁石が $0.25 \mathrm{mNm}$ に対し, 焼結磁石 はコギングトルクが大きかったため, ボンド磁石の 10 倍の $2.5 \mathrm{mNm}$ になっている.

次数分析結果より, ボンド磁石は 12th, 18th, 24th, 27th, 36th が大きく発生しており, 焼結磁石でも同じ次数が現れ ている.

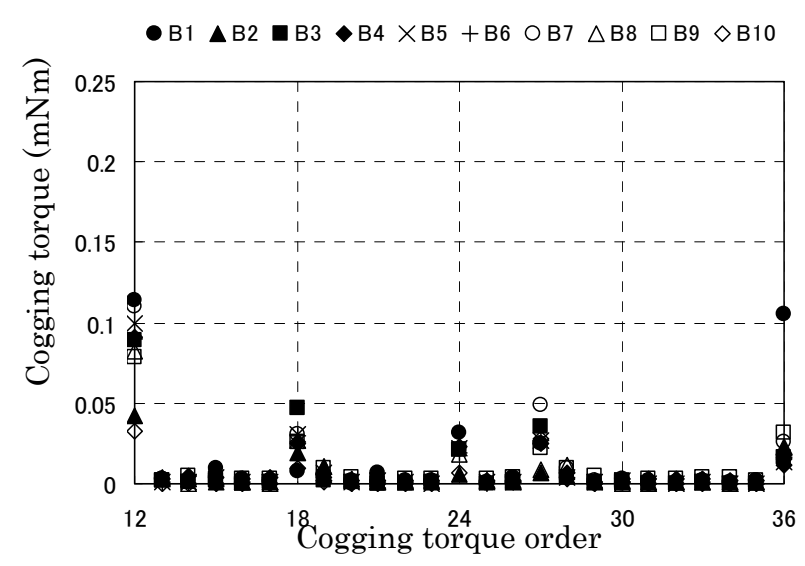

Fig. 5 Analysis of order number of induced torque in bonded magnet.

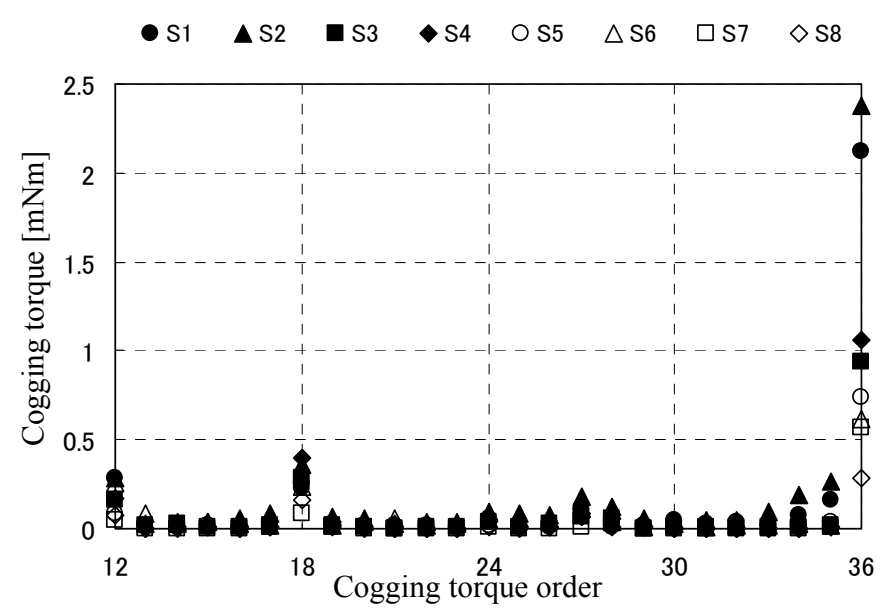

Fig. 6 Analysis of order number of induced torque in sintered magnet.

しかし, 焼結磁石に比ベボンド磁石ではコギングトルク があまり出ていない。 ボンド磁石は磁束密度が低いためコ ギングトルクは小さいことが予想されるが，このボンド磁 石を用いたモータは実際に製品モータに使用されコギング トルク低減がなされているためコギングトルクが小さい.

また，焼結磁石は磁束密度が高く，コギングトルクが大 きくなっている.

\section{2 誘起起電力の高調波次数}

Fig.5, Fig.6よりコギングトルクが出ていた次数について 磁束密度高調波次数の振幅を調べた.

Fig.7, Fig.8 から回転子磁石別での高調波次数分析結果 によって，ボンド磁石，焼結磁石ともに 12th，18th，24th， 27th，36th での振幅が出ていることが分かる.

このことから次の章では各次数について回転子磁石とコ ギングトルクの関係性についての検討を行う.

- $\mathrm{B} 1 \Delta \mathrm{B} 2 \boldsymbol{\mathrm { B }} 3 \bullet \mathrm{B} 4 \times \mathrm{B} 5+\mathrm{B} 6$ OB7 $\triangle \mathrm{B} 8 \square \mathrm{B} 9 \diamond \mathrm{B} 10$

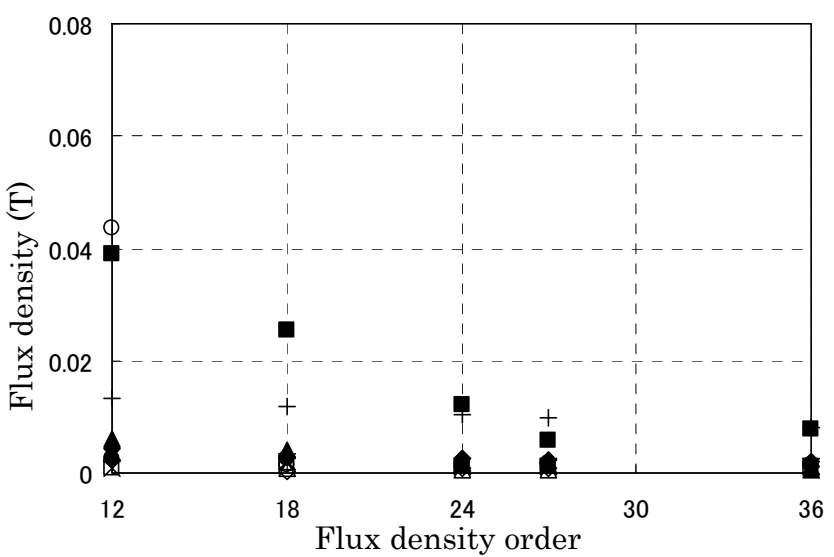

Fig. 7 Analysis of order number of flux density. (bonded magnet) 


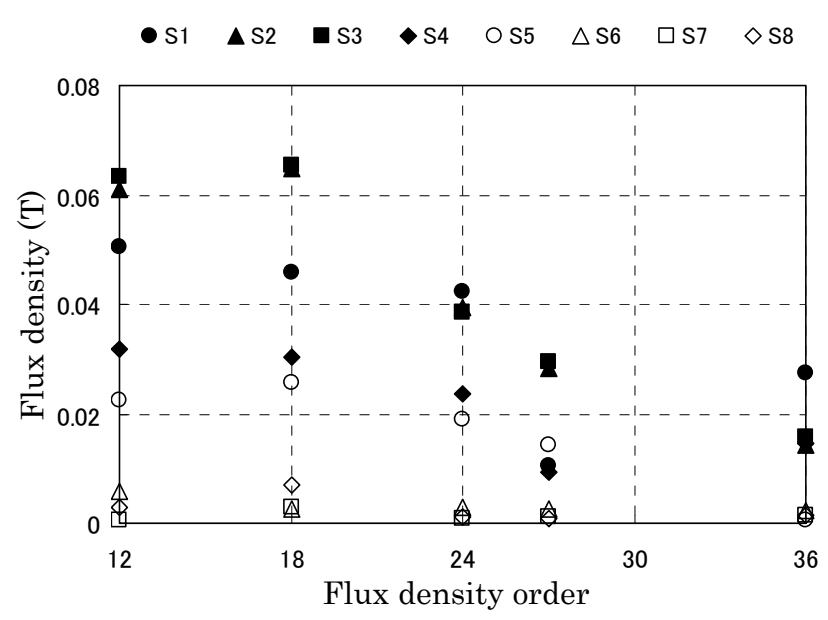

Fig. 8 Analysis of order number of flux density. (sintered magnet)

\section{4. 次数の関連性}

誘起起電力の次数分析結果（Fig.7, Fig8）で分かったよ うに次数ごとの振幅とコギングトルクの関係性を把握する ためグラフ化してみる。

\section{1 回転子磁石別コギングトルクの分析}

ボンド磁石でのコギングトルク分析を Fig.9, 焼結磁石で のコギングトルク分析を Fig.10 に示寸.

グラフの縦軸はボンド磁石が $0.25 \mathrm{mNm}$ に対し, 焼結磁 石はボンド磁石の 10 倍の $2.5 \mathrm{mNm}$ になっている.

ボンド磁石では Fig.9を見るとわかるように 12 th がコギ ングトルクの振幅が大きくなっていることが分かる。これ は鉄心におけるかしめ部歪の影響であることが既に示され ている3゙.

焼結磁石では Fig.10 より 36th でのコギングトルクが他 の次数に比べ非常に大きくなっていることがわかる.これ は鉄心磁束密度が高く, 着磁次数 (12 極) とスロット数 (9 ス ロット)から生じるコギングトルクの最小公倍数次数であ る基本次数が現れている.

\section{2 コギングトルクと磁束密度の関係性}

このように, 鉄心磁束密度が高くなると 36th のコギング トルクが大きくなっているので， 36th コギングトルクに 関係する鉄心磁束密度次数 36th 成分とコギングトルク 36th 成分の関係について調べてみた。 その結果を Fig.11, Fig.12 に示寸.

ボンド磁石では Fig.11 より，36th コギングトルクと磁 束密度高調波成分 36 th との相関は殆どない。 これは磁束 密度の 36th 成分も 0.01T 以下であり, 鉄心が磁気飽和し ていないためであり，更に，実機モータで前述のように鉄 心形状調整や着磁分布調整などのコギング低隇対策がなさ れているためと考えられる.
焼結磁石では Fig. 12 より磁気飽和で 0.01T 以上の磁束密 度 36th 成分が発生し, コギングトルク 36th と磁束密度 36th 成分には強い相関があることが明らかであり，鉄心 の磁気飽和により，磁束密度高調波成分 36th が発生しコ ギングトルクが大きくなったことがわかる.

以上より，モータの回転子磁石に希土類焼結磁石を用い ると、コギングトルクが大きくなった。これは固定子鉄心 の磁気飽和の影響と推察される。しかし, 鉄心磁束密度に 含まれる磁気飽和による磁束密度歪み，すなわち高調波成 分は多少大きくなったが，予想ほど大きくなかった。これ は鉄心が磁気飽和に近づいても，回転子と固定子間の空隙 や永久磁石の影響が強く，磁石のパーミアンス係数にあま り影響しなかったため，予想ほど高調波は発生しなかった と考えられる. 従って，コギングトルクの発生原因は鉄心 の磁気飽和による鉄心の非線形特性の影響だけでは説明出 来ない.

12th $\triangle 18$ th $\square 24$ th $\diamond 27$ th $\times 36$ th

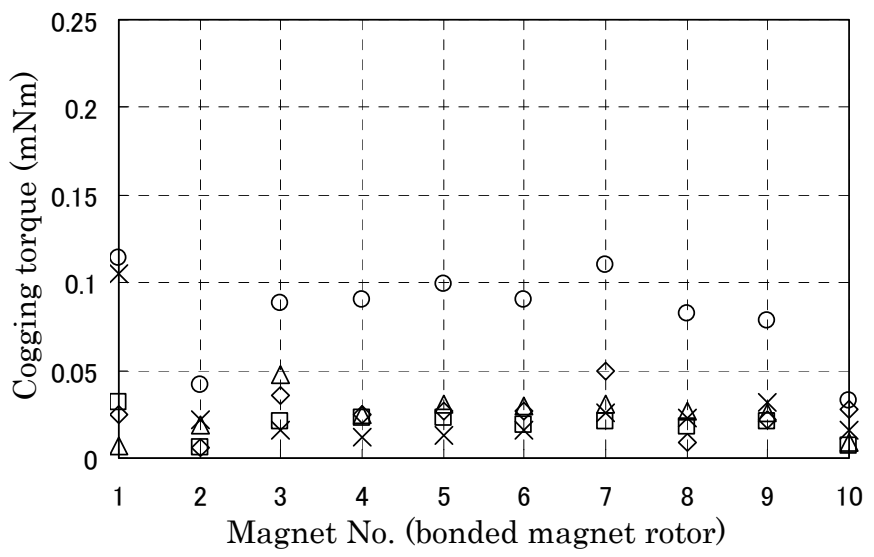

Fig. 9 Harmonics of cogging torque (bonded magnet).

O 12th $\triangle 18$ th $\square 24$ th $\diamond 27$ th $\times 36$ th

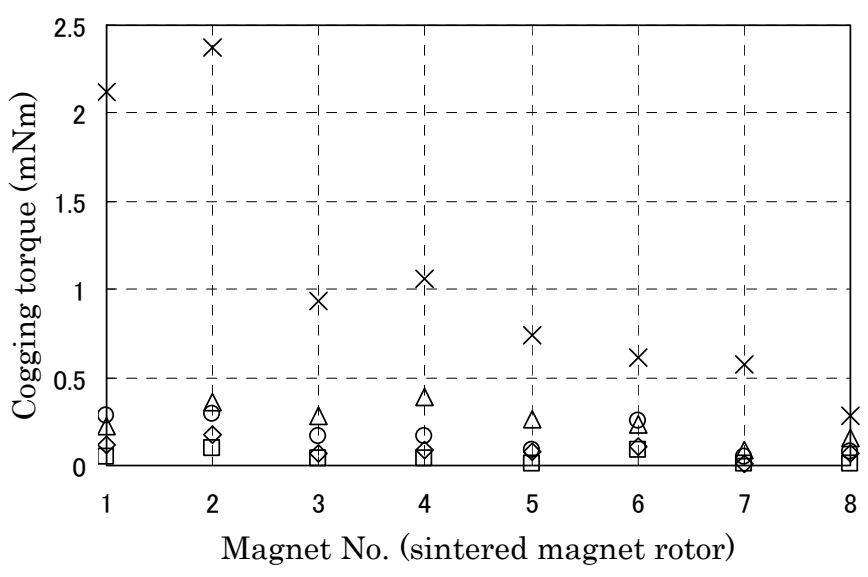

Fig. 10 Harmonics of cogging torque. (sintered magnet) 


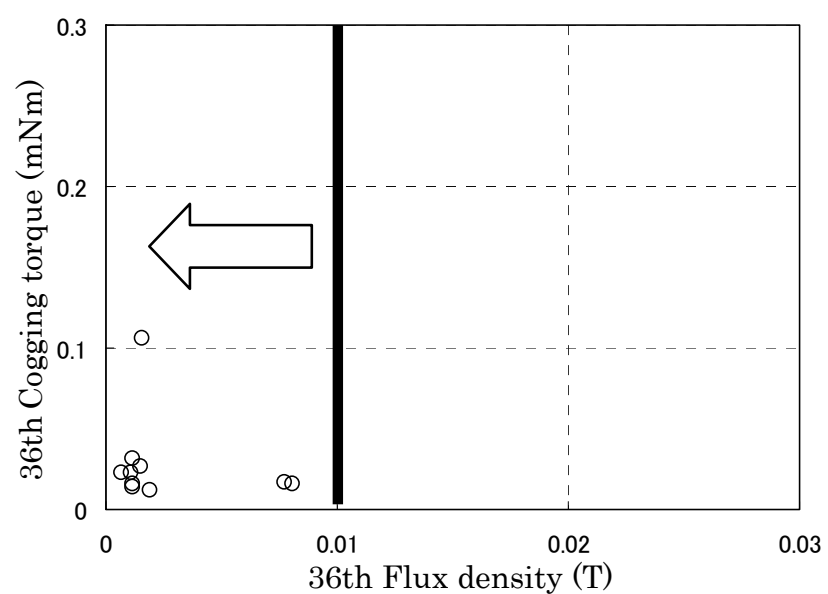

Fig. 11 Relationship between 36th harmonics of cogging torque and harmonics 36th harmonics of core flux density in bonded magnet motors.

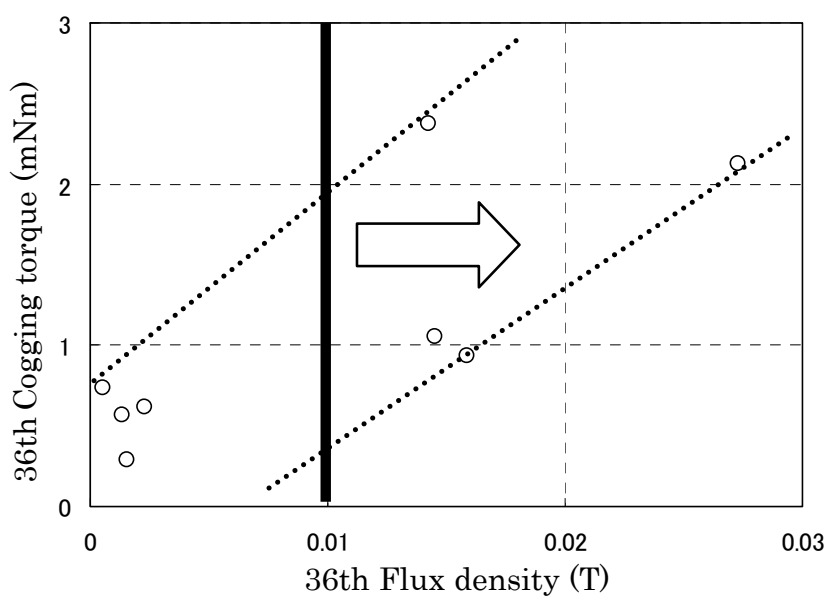

Fig. 12 Relationship between 36th harmonics of cogging torque and harmonics 36th harmonics of core flux density in sintered magnet motors.

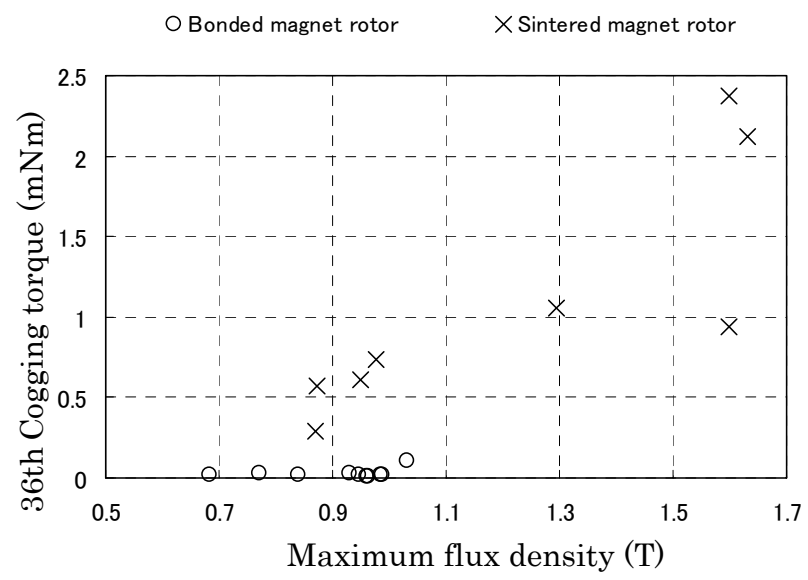

Fig. 13 Relationship between 36th harmonics of cogging torque and maximum flux density in bonded magnet and sintered magnet motors.
そこで，他のコギングトルク発生原因を考えてみた。 $36 \mathrm{th}$ コギングトルクの発生は鉄心磁気飽和による磁束高 調波発生だけではなく，鉄心磁気飽和による鉄心透磁率の 低減も原因の一つと推察される。

そこで，コギングトルクと鉄心の最大磁束密度の関係に ついて調べてみた。 その結果を Fig.13に示した。この結 果により，鉄心の最大磁束密度の影響が明確に現れている ことがわかる。従って，1 T 以下でコギングトルク低減 の鉄心形状調整されていても，磁気飽和により透磁率が低 下し，磁気回路的に調整されていたコギング低減条件から 外れたためコギングトルクが大きくなったと考えられる.

実際に，鉄心磁気飽和による透磁率変化を調べてみた。

Fig.14より鉄心素材 35A250 の比透磁率 5) は $1 \mathrm{~T}$ で 10000 程度であるのに対して，1.6 T では 500 以下であり，一桁 以上の低下になる。使用したモータにおいて, 磁石厚さ 1 $\mathrm{mm}$ に対して, 空隙 $0.25 \mathrm{~mm}$ になっている. 一方, 磁石 厚さ $1 \mathrm{~mm}$ に対して，鉄心磁路長約 $5 \mathrm{~mm}$ であり，空隙換 算の実効磁路長は $1 \mathrm{~T}$ では約 $1 \mu \mathrm{m}$ 以下になり, パーミア ンス係数 4 に殆ど影響しないが, $1.6 \mathrm{~T}$ では空隙換算の実効 磁路長は $0.01 \mathrm{~mm}$ となり, パーミアンス係数に約 $4 \%$ 影響 をあたえるので，コギングトルクに鉄心が影響する。

今回，モータのコギングトルクと鉄心磁気飽和の関係を 鉄心歯部の磁束密度で検討してみた。モータ内の磁束の流 れとして Fig.15のように今回検討した $\Phi 1$ 以外に鉄心歯先 を流れる $\Phi 2$ も考慮する必要がある。今後は回転子と固定 子閒の空隙が狭いため困難である $\Phi 2$ の測定を検討し，鉄 心外形を変えて $\Phi 2$ を変化させ, $\Phi 2$ の影響を調べることも 必要と考える. また, 鉄心素材に, 電磁鋼板より飽和磁 化が高い材料(FeCo 材など)を用いて， $\Phi 1$ の影響について も検討する必要がある。

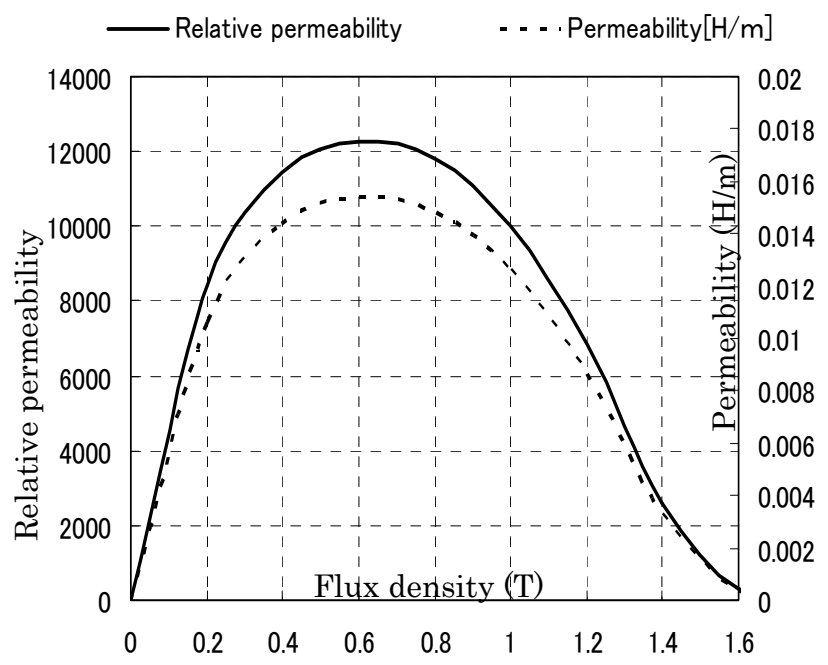

Fig. 14 Effect of flux density on permeability [35A250]. 


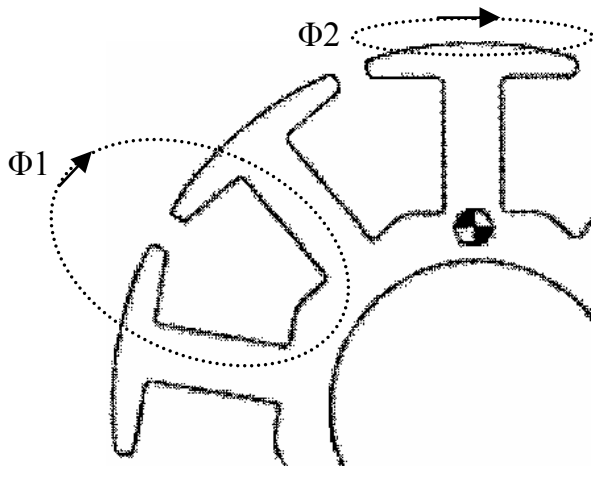

Fig. 15 Flow of flux in magnetic induction.

\section{5. 結論}

今回, 着磁磁束密度の異なる永久磁石と着磁磁束を変え てコギングトルクを測定し，鉄心磁気飽和によるコギング トルク増大の原因を調べた。焼結磁石のように着磁磁束密 度が高いと，コギングが大きく特に $36 \mathrm{th}$ が大きかった. 着 磁方法による影響も出ているようであるが，鉄心磁気飽和 の影響が強いと考えられる。

そこで, 鉄心磁束密度の高周波成分と 36th コギングの高 周波成分を調べたところ, 磁気飽和により磁束密度高調波 は大きくなり，コギングトルク 36th 成分の増加と相関が見 られた。しかし，磁気飽和によるコギングトルクの増大現 象を十分に説明できるほど，高調波の発生は大きくなくか った，従って，コギングトルク発生の他の要因として，鉄 心磁気飽和による透磁率の低下がもう一つの要因と考えら れる.また，鉄心歯先のみを流れる磁束 $\Phi 2$ の影響も考え
られるので, これらの要因についても検討する予定である.

今後は希土類磁石により鉄心が磁気飽和しコギングトル クは増大し, モータの高出力化とコギングトルクの低減を 合わせ行うことが求められる．磁気飽和は非線形挙動であ り, 磁石により発生する磁束密度に加えて, 電機子電流に よる磁束密度も加わると，鉄心透磁率も変化するので，モ 一タ駆動状態でコギングトルクも増大寸ることが考えら れ，モータの高出力化とコギングトルクの低減を両立する 為には今後の詳細な研究が必要となると予想する.

謝辞 本研究を推進するにあたり，ソニー株式会社の宍戸 祐司氏，金子祥子氏，橋本寿雄氏，木村徹氏および日立金 属株式会社の谷川茂樹氏にご協力を賜りましたことを深く 感謝致します.

\section{References}

1) C. Kaido, J. Yamasaki, K. Hanzawa, S. Kaneko, T. Hashimoto, T. Kimura, and Y. Shishido : "Core Material Parameter Analysis of Torque Characteristics of Small Motor",IEEJ Trans. IA, Vol.126-D, No.12, (2006) pp.1708-1711.

2) IEEJ Technical Report No.855(2001), pp.31-37.

3) C. Kaido, J. Yamasaki, H. Mogi, T. Kubota, S. Kaneko, Y. Shishido, and S. Kitagawa: "Discussion on Core Dependence of Motor Cogging Torque", The Papers of Technical Meeting on Rotating Machinery, IEE Japan, RM-07-58(2007)

4) Japanese Industrial Standard JIS C 2552:2000, "Non-oriented Magnetic Steel Sheet and Strip", (2000).

5) Nippon Steel Corporation Catalog Cat. No.DE 106, "HILITECORE, HOMECORE, Non־oriented Electrical Steel Sheets", (1999) p.27.

2010年10月20日受理，2011年1月31日再受理，2011年3月3日採録 